\title{
EXPERIMENTAL LIFE CYCLE OF CONTRACAECUM QUADRIPAPILLATUM N. SP. IN WHITE PELICAN (PELECANUS ERYTHRORHYNCHUS) AT LAKE NASSER, EGYPT: MORPHOLOGICAL AND GENETIC EVIDENCES

\author{
By \\ ATEF IBRAHIM SAAD ${ }^{1^{*}}$, ABUELHASSAN ELSHAZLY YOUNIS ${ }^{1}$ \\ and JIHAN MOHARAM RABEI ${ }^{2}$
}

Department of Zoology ${ }^{1}$, Faculty of Science, Aswan University, 81528 Aswan, and Fishery Management Center ${ }^{2}$, High Dam Lake Development Authority, Aswan, Egypt ("Correspondence: SAAD:atefsaad2002@yahoo.com; +2097 3480447)

\section{Abstract}

During November 2013 to October 2015, one hundred and nine fish specimens of Clarias lazera were captured from different areas of Lake Nasser, South Egypt. They were found infected with $3^{\text {rd }}$ stage larvae of Contracaecum with $100 \%$ prevalence. $4^{\text {th }}$ stage larvae and adults were experimentally obtained from the lower part of esophagus of white Pelicans $\mathrm{Pel}$ ecanus erythrorhynchus previously administered $3^{\text {rd }}$ stage larvae. Detailed morphological description of both larvae (L3) and adults, by light and scanning electron microscopes as well as molecular analysis of the internal transcribed spacers of nuclear ribosomal DNA (ITS-1 \& ITS-2) indicated the presence of a new Contracaecum sp. here named C. quadripapillatum $\mathrm{n}$. $\mathrm{sp}$.

Keywords: Egypt, Internal transcribed spacers; Lake Nasser; Contracaecum; Clarias lazera GenBank database: Sequences of ITS-1 and ITS-2 of Contracaecum quadripapillatum n. sp. have been deposited to the GenBank database under accession numbers KY703768 and KY703769, respectively.

\section{Introduction}

Anisakidosis is a famous zoonotic disease of major public health and economic importance. It is resulting from the accidental infestation with anisakid nematode larvae due to the consumption of infected raw or undercooked fish (Sakanari and McKerrow, 1989; Palm, 2004). The larvae invade the gastrointestinal tract of humans and cause eosinophilic granuloma syndrome (Kaneko, 1991). The highest prevalent areas were Scandinavia (from cod livers), Japan (from sushi and sashimi), Netherlands (from herrings) and along the pacific coast of South America from ceviche (Audicana et al, 2002). These nematodes are parasitizing many fishes and aquatic invertebrates which considered intermediate or paratenic hosts, while marine mammals and piscivorous birds are definitive hosts.

Larval stages of Contracaecum (Railliet and Henry, 1912) are usually found in the body cavity of fish while adults are found in the gut of birds, such as pelicans, cormorants, herons and darters (Whitfield and Heeg, 1977). Clarias lazera is the commonest clariid in Lake Nasser and its local name is Hout or Karmout (Latif, 1974). Several studies on the presence of Contracaecum larvae in cichlid and catfish especially Clarias spp. were widely achieved in African lakes, (Yimer and Enyew, 2003; Barson, 2004; Moyo and Barson, 2010; Amare et al, 2014). Several species of fish and cephalopods act as intermediate hosts for this nematode species (Anderson, 1992; Køie and Fagerholm, 1995; Køie et al, 1995). In the fish, the third stage larvae migrated from the intestine to the body cavity and encapsulated there. If small fishes are eaten by larger fishes, the larvae can re-infect the latter without molting, and accordingly larger fishes may accumulate an enormous number of larvae (Lile, 1998). A total of 12 marine mammal species and different fish eating birds have been identified as final hosts of Contracaecum (Torres et al, 1983; William et al, 2002; Dronen et al, 2003; Farjallah et al, 2008; 
Mattiucci and Nascetti, 2008; Shamsi et al, 2009).

Approximately 100 species of Contracaecum were identified. However, further taxonomic revisions are needed. Some species of similar morphology are differed genetically and therefore divided into two or more sibling species. The internal transcribed spacer sequences of nuclear ribosomal DNA (ITS-1 and ITS-2) provide well established and useful genetic markers (Zhu et al, 1998; 2000a; 2001b; Shih, 2004; Nadler et al, 2005; Klimpel et al, 2007). A continually expanding list of ITS-1 and ITS-2 sequences from anisakids and other nematodes is publicly available at the GenBank database.

Younis et al. (2017) reported larvae collected from four teleostian fish species in Lake Nasser, belonged to the genus Contracaecum. Based on morphological and molecular differences between the collected larvae some were, likely to represent $C$. multipapillatum with the possibility of more than one species present. The C. multipapillatum is a complex containing about four distinct species found in the USA, Europe and Australia (Nadler et al, 2000; Mattiucci et al, 2010; D'Amelio et al, 2007; Shamsi et al, 2008).

Now the question remained: How many species of Contracaecum infected Lake Nasser fish? Is there a new species (fifth species) of the $C$. multipapillatum complex. To answer this question, the life cycles of the larvae have to be completed to examine the adult stages as well. The discovery of new species, contribute to fulfill the inventory of biodiversity, and it is of particular interest for parasitic species with a potential impact of the human health. A biological system is developed, in order to investigate the biological life cycle of the presumptive new species analyzed, monitoring the subsequent larval stages to the adult form.

Based on integrated morphological and molecular investigations, the present work indicated the presence of a new Contracaecum sp. in the fish Clarias lazera from Lake Nasser.

\section{Materials and Methods}

Fish: Regulations and guidelines of Aswan University were performed in terms of dealing with animals. Agreements of the Committee of Research and Post-Graduate Studies, Aswan University were approved before starting the study.

With permission from the Fishery Management Center, High Dam Lake Development Authority at Aswan city, one hundred and nine fish specimens of Clarias lazera were collected from Lake Nasser during November 2013 to October 2015. Fish were immediately transported to the laboratory for anisakid parasite examination. They were dissected and body cavity, alimentary tract, liver and gills were taken out and examined in physiological saline.

Experimental development of adults: The third stage larvae were collected from the body cavity of the fish and washed extensively in physiological saline. Larvae were processed, for morphological and molecular studies, as recently described (Younis et al, 2017). In brief, each individual larva was divided into three pieces. The middle parts were kept in $-20^{\circ} \mathrm{C}$ in $70 \%$ ethanol for molecular study. For morphological identification, anterior and posterior parts were fixed in warm $70 \%$ ethanol $\left(60-70^{\circ} \mathrm{C}\right)$ and preserved in $70 \%$ ethanol with few drops of glycerin.

Two adult white Pelicans (Pelecanus erythrorhynchus) were caught from the Lake area and transported to the laboratory. Their feces were found free of helminthes ova during daily examination for a week. For confirmation, using a gastric tube, birds were orally administered anthelminthic drugs according to the pelican weight (a single dose of Praziquantel and two doses of Mebendazole, in two days interval). One week later, the helminthes-free pelicans were orally fed 300 Contracaecum larvae by mean of gastric tubing. The infection was repeated on day $18^{\text {th }}$ post-infection. Feces were examined daily for the presence of ova. Following confirmation of infection, pelicans were dissected on 
the $20^{\text {th }}$ day post-infection. $4^{\text {th }}$ larvae, adult females and adult males of Contracaecum sp. were collected and processed as mentioned above.

Morphological examination: Worms were cleared in lactophenol for 24 hours for light microscopic study. Drawings were made using the drawing tube and all measurements were given in millimeters, unless otherwise mentioned. Photomicrographs were taken of nematodes obtained by using digital microscope (Olympus CX41). Identification was according to keys and descriptions (Yamaguti, 1961; Nadler and Hudspeth, 1998; Anderson, 2000; Martins et al, 2005; Olivero-Verbel et al, 2006). For the scanning electron microscope examinations, specimens were fixed in 5\% glutaraldehyde solution for 24 hours, and washed in Sodium cacodylate buffer solution 3-5 times (15 minutes each). Post-fixation of specimens were made in $1 \%$ of osmic acid for 2 hours, then washing was done; five changes in Sodium cacodylate buffer solution (15 minutes each). Dehydration of the specimens was done in ascending grade of ethanol; 30, 50, 70, 90 \& $100 \%$ (30 minutes each). Then the specimens were dried to the critical point by exposing to $25^{\circ} \mathrm{C}$. After that, they were placed on the holder and were coated at high vacuum by a very thin layer of gold (thickness of 150-200 Angstroms). Finally, the specimens were examined by scanning electron microscope (Jeol: JSM 5400 LV).

Molecular analyses: Genomic DNA isolation, PCR and sequencing: Genomic DNA extracted from individual larvae or adult worms by phenol/chlorophorm method (Younis et al, 2011). Briefly, individual parasite materials were digested overnight at $56^{\circ} \mathrm{C}$ with proteinase $\mathrm{K}$ in ALT buffer (Dneasy kit, Qiagen) under a constant agitation, after that precipitated with $5.2 \mathrm{M}$ ammonium acetate. Samples were diluted in 20-50 $\mu \mathrm{d} \mathrm{H}_{2} \mathrm{O}$ (HPLC Water) depending on the pellet size, concentrations were determined by spectrophotometry.
Amplification the two nuclear ribosomal markers were takes place using the specific primer sets SS1/ NC13R (for ITS-1) and SS2/NC2 (for ITS-2) under the similar conditions as described previously (Zhang et al, 2007). The PCR $(50 \mu l)$ was performed in thermo-cycler under the following conditions: initial denaturation at $94^{\circ} \mathrm{C}$ for $5 \mathrm{~min}$ utes, then 35 cycles of $94^{\circ} \mathrm{C}$ denaturation temperature for 30 seconds, $55^{\circ} \mathrm{C}$ annealing temperature for 30 seconds and $72^{\circ} \mathrm{C}$ elongation temperature for 30 seconds, followed by $72^{\circ} \mathrm{C}$ for 5 minutes. Samples with fish/ bird gDNA or without gDNA were included in the PCR as controls. PCR products were analyzed by $1.2 \% \mathrm{w} / \mathrm{v}$ agarose gel, stained with ethidium bromide and photographed using a UV gel documentation unit (UVPBioDoc-IT). Positive PCR products were then purified using DNA Clean and Concentrator TM-25 kit (Zymo Research, USA) according to the manufacturer's protocols. The purified products were sent for sequencing to Macrogen Inc. (Korea), via National BioLab for trade (Cairo, Egypt). Samples were sequenced by a dideoxy termination method using an applied biosystems sequencer model 3730XL automated DNA sequencing system (Applied BioSystems, USA), in the two directions (forward and reverse) by the same PCR-used primers.

Computer-based sequence analysis: Each sequence (forward) was compared to its complement (reverse) and then assembled by cap3 software or manually. The resulted sequences were individually compared to other sequences available at the database using NCBI Blast program for homology search (http://www.ncbi.nlm.nih.gov). Subsequently, they were aligned to each other and to the most homologous sequences in the database using CLUSTALW and/or MUSCLE multiple sequence alignment programs. The phylogenetic analysis was cond ucted using online tool software Phylogeny.fr program (Dereeper et al, 2008).

\section{Results}

Morphological Identification: Third stage 
larvae of Contraceacum obtained from $C$. lazera $(\mathrm{n}=10)$ : All examined C. lazera $(109$ specimens) were found infected with $\mathrm{L}_{3}$ of Contracaecum sp. (prevalence 100\%). Larvae were found in the body cavity adhering to the alimentary canal. The burden of larvae was 35-116 larvae/fish. They were reddishyellow in colour and covered with a smooth transparent cuticle. The body was 15-35 (av. (average) 23) in length and 0.94-1.56 (av. 1.35) wide. The mouth was surrounded by three small lips with a prominent papilla and a well-defined boring tooth measuring 0.020.03 (av. 0.024). Esophagus was narrow and long, 2.6-4.12 (av. 3.6) long, 14-17.3\% (15.6\%) of body length and 0.1-0.14 (av. 0.13 ) wide. Ventricular appendix was 0.861.04 (av. 0.93) long and 25-33\% (25.8\%) of esophageal length. Intestinal caecum measured 1.72-3.3 (av. 2.77) long and 66-80\% (76.9\%) of esophageal length. The ratio of ventricular appendix to intestinal caecum was $31.5-50 \%(33.5 \%)$. The intestine was opening ventrally in a slit-like shape anus and tail was conical in shape measured 0.10.16 (av. 0.12 ) long and $0.5-0.6 \%(0.5 \%)$ of body length, with a tapered process measured 0.04-0.06 (av. 0.045). The rectum was provided with rectal cells.

SEM (Fig. 1a, b) showed the transversely striated cuticle and cuticular ridges at head region which were narrow anteriorly and became wider posterioly without host mucus. The mouth opening was triangular and surrounded by three small lips, one dorsal and two ventral, which are provided with four papillae, two on the dorsal lip and one on each ventral lip, well defined boring tooth located on dorsal lip, excretory pore located anteriorly in between the two ventral lips.

Fourth- stage larvae of Contracaecum obtained from Pelicans $(n=10)$ : Living specimens of $4^{\text {th }}$ larvae of Contracaecum were found freely in the lower part of esophagus of the Pelican after two days post-infection. They were very active and lived for 24 hours in saline solution (life span). The body was elongated, cylindrical and yellowish in col- our. Nerve ring appeared circling the esophagus and was located at the first third of its length. Cuticle ridges were more distinct on the cephalic and caudal ends. The body was 30-40 (av. 35) long and 0.9-1.06 (av. 0.96) wide. Esophagus measured 2.6-3.3 (av. 2.98) long, 8.7-12.8\% (9.4\%) of body length and 0.1-0.14 (av. 0.13) wide. Ventricular appendix was 0.94-1.12 (av. 1.07) long and $35.9-42.3 \%(33.9 \%)$ of esophageal length. The intestinal caecum was 1.32-2.76 (av. 2.08) long, 50.7-84.8\% (69.8\%) of esophageal length and 0.28-0.3 (av. 0.29) wide. The ratio between ventricular appendix to intestinal caecum was $40.5-70 \%(51.4 \%)$. The tail was pointed measured $0.12-0.22$ (av. 0.18) long, 0.4-0.55\% (0.5\%) of body length and ended with a tapered process measured 0.025-0.03 (av. 0.028). The rectum was provided with rectal cells. SEM showed that cuticle was smooth and striation was less distinct than the $3^{\text {rd }}$ stage larvae, the head region had cuticular ridges with heavy mucus derived from the host and were narrow anteriorly then became wider posteriorly. Mouth opening was triangular and surrounded by three ill-defined lips, one dorsal and two sub-ventral. The excretory pore was located anteriorly between the two subventral lips. Four papillae were found, one on each ventral labium around the excretory pore and two on the dorsal labium (Fig. 2 a). Anal opening was located ventrally near the posterior end. The molting of this stage (Fig. $2 \mathrm{~b}, \mathrm{c})$ began from the body posterior part.

Adult worms were found in lower part of esophagus of Pelican, ten days postinfection. The body was elongate and cylindrical, three lips (one dorsal and two lateroventral) interceded with interlabia, were present surrounded by a prominent collar, interrupted laterally at the base of lips. Visible depression (groove) was noticed ventrally in each labium. Two ovate papillae on the dorsal labium were found and one papilla on each sub-ventral labium. Interlabia were triangular in shape with wide base and had the same heights as lips (Figs. 3a \& 4a,d). Intes- 
tinal caecum was about three to four times longer than ventricular appendix (Figs. 3b \& $4 b)$. The anal opening was located near the posterior end.

Male ( $n=10)$ : Body length 25-27 (av. 26) long and width 0.96-1 (av. 0.98). Esophagus measured 3.6-4.5 (av.4.05) long, 14.4-16.6\% (15.6\%) of body length and 0.12-0.2 (av. $0.16)$ wide. Ventricular appendix 0.78-1.1 (av. 0.93) long and 21.7-25.6\% (23.5\%) of esophageal length. Intestinal caecum 2.8-4.1 (av. 3.45) long, 77.8-87\% (85.2\%) of esophageal length and 0.24 (av. 0.24) wide. The ratio between ventricular appendix to intestinal caecum was $27.9-31.4 \%$ (29.5\%). Tail was pointed, curved ventrally and ended with a tapered process; it measured 0.120.16 (av. 0.14) long, $0.5-0.6 \%(0.6 \%)$ of body length. The seminal vesicle was long and opened in the cloacal opening, two subequal spicules were present and provided with transparent membrane (Figs. 3 c \& 4 c). Right spicule measured 2.04-2.54 (av. 2.12) long, $8.2-9.4 \%$ (8\%) of body length. Left spicule 2-2.24 (av. 2.11), long 8-9\% (8\%) of body length.

SEM studies indicated that post-anal papillae consist of one pair of small papillae at level of cloaca, followed by one pair of double papillae. Remaining post-cloacal papillae arranged in three rows, first and second rows containing four papillae on each side forming quadrilateral shape and the third has one papilla on each side (Figs. $3 \mathrm{~d} \& 4$ e). The cuticle was smooth and striated transversely and longitudinally.

Female $(n=10)$ : Body measured 29-36 (av. 33) long \& 0.9-1.4 (av. 1.19) wide. Esophagus measured 3.6-4.6 (av. 4.13) long, $10.3-15.2 \%(12.4 \%)$ of body length \& $0.12-$ 0.18 (av. 0.14) wide. Ventricular appendix 0.9-1.12mm (av. 1.01) long, \& 24.3-26.2\% (25.6\%) of esophageal length. Intestinal caecum 2.4-3.9 (av. 3.3) long, 66.7-88.6\% (79.5\%) of esophageal length \& 0.2-0.4 (av. 0.32 ) wide. The ratio between ventricular appendix to intestinal caecum 26.5-39.2\% $(32.04 \%)$. Tail ended with a tapered process and measured 0.2-0.48 (av. 0.32) long, 0.5$1.3 \%(0.9 \%)$ of body length. The muscular genital pore was situated at a distance of 812.24 (av. 10.91) from the anterior end and surrounded by small papillae (Fig. 4 f). Eggs were immature, spherical and measured 2348 (39) $\times 35-49$ (48) $\mu \mathrm{m}$ in diameter.

Morphological comparison of C. quadripapillatum $\mathrm{n}$. $\mathrm{sp}$. with other related species: Although the morphological characters of the present worms resemble that of previously described four species of Contracaecum multipapillatum A, B, C and D (Nadler et al, 2000; Mattiucci et al, 2010; D'Amelio et al, 2007; Shamsi et al, 2008), it showed unique morphological differences. The differences are: the site of infection where the present worms found in the lower part of esophagus but $C$. multipapillatum always found in proventriculus and stomach of the bird; the number and arrangement pattern of post-cloacal papillae in the present males were five forming a quadrate shape while in C. multipapillatum, were four papillae forming L shape (Shamsi et al, 2008). Moreover, spicule lengths were sub-equal and longer than those of $C$. multipapillatum described from Egretta alba in Colombia, C. multipapillatum sp. A (C. gibsoni) from Pelecanus crispus in the Ambracian Gulf off Greece and $C$. multipapillatum sp. D from Austalian pelican (D'Amelio et al, 2007; Shamsi et al, 2008; Mattiucci et al, 2010) but, shorter than those of $C$. multipapillatum (=C. robustum) identified from birds in Northern Gulf of Mexico by Deardorff and Overstreet (1980) and C. multipapillatum sp. B (C. overstreeti) from the Dalmatian pelica Pelecanus crispus in the Ambracian Gulf off Greece (Mattiucci et al, 2010). Besides, the tips of the present spicules were rounded while they were pointed in $C$. gibsoni, $C$. overstreeti and C. multipapillatum sp. D.

Adult male and female of $C$. quadripapillatum n. sp. were deposited in the public museum of the Zoology Department, Faculty of Science, Aswan University under the deposition code (Zoo-Inv-Nem.Cq.01/ 2017). 
Molecular characterization and phylogenetic analysis: Agarose gels analyses of the PCR products which resulted from gDNA of Contracaecum larvae as well as gDNA of adult males showed amplicons of $\sim 530 \mathrm{bp}$ and $\sim 430$ bp for the ITS-1 \& ITS-2 respectively. As expected sequences of ITS-1 and ITS-2 of L3 and adults were $100 \%$ identical and have been deposited to GenBank database under accession numbers (KY703768 and KY703769), respectively.

No high similarities found neither for ITS1 nor ITS-2 with other sequences from Contracaecum adults. But, (Tab. 1), blast search and alignments of ITS-1 sequence showed the highest to typical identities $(99 \%$ and $100 \%$ ) to our recently identified ITS-1 sequences (accession numbers KX580604 and KX580607) of L3 (short form) collected from Hydrocynus forskahlii and L3 (short form) collected from Lates niloticus (Younis et al, 2017). In addition it showed a very high identity (98\%) to the ITS-1 sequences (Accession numbers FM210433-FM210434FM210435) of L3 collected from intestine \& body cavity of barboid fishes in Parishan Lake, Iran (Shamsi and Aghazadeh-Meshgi, 2011). In (Tab. 2), ITS-2 sequence showed highest similarity (99\%) to two ITS-2 sequences (accession numbers KX580610 and KX580612) from L3 of L. niloticus and $H$. forskahlii (Younis et al, 2017). It showed high similarity (98\%) to ITS-2 sequences of the Contracaecum larvae (Accession numbers FM210437- FM210438- FM210439) isolated from Iranian fish (Unpublished data, recorded by Shamsi in 2008 to the GenBank). It is likely that L3 which were identified recently to belong to $C$. multipapillatum complex (Younis et al, 2017) and were collected from H. forskahlii and L. niloticus in Lake Nasser, are of the same species of the larvae collected from $C$. lazera in the present work (C. quadripapillatum). After experimental development of adult stages, morphological description and molecular analysis revealed that larvae collected in this study from $C$. lazera represent a new species of Contacaecum and four types of larvae (short forms collected from $H$. forskahlii and L. niloticus (Younis et al, 2017) and those collected from Iranian barboid fishes (Shamsi and Aghazadeh-Meshgi, 2011) and larvae collected from $C$. lazera (present work) are likely belonging to $C$. quadripapillatum n. sp.

Phylogenetic trees of the aligned ITS-1 and ITS-2 showed similar results, the earlier presented (Fig. 5). Thus, sequences from L3, collected previously from $H$. forskahlii and L. niloticus (Lake Nasser, Egypt) and those of L3 found in barboid fishes (Parishan Lake, Iran) are very closely related to the new species Contracaecum quadripapillatum.

\begin{tabular}{|c|c|c|c|}
\hline Accession & Identity & Source (L3/adult worms) & References \\
\hline KX580607 & $100 \%$ & $\begin{array}{l}\text { Third stage larvae (short form) of Contracaecum sp. } \\
\text { found in Lates niloticus (Lake Nasser, Egypt) }\end{array}$ & Younis et al 2017 \\
\hline KX580604 & $99 \%$ & $\begin{array}{l}\text { Third stage larvae (short form) of Contracaecum sp. } \\
\text { found in Hydrocynus forskahlii (Lake Nasser, Egypt) }\end{array}$ & Younis et al 2017 \\
\hline $\begin{array}{l}\text { FM210433 } \\
\text { FM210434 } \\
\text { FM210435 }\end{array}$ & $98 \%$ & $\begin{array}{l}\text { Third stage larvae of Contracaecum sp. found in } \\
\text { barboid fishes (Parishan Lake, Iran) }\end{array}$ & $\begin{array}{l}\text { Shamsi and Aghaza- } \\
\text { deh-Meshgi } 2011\end{array}$ \\
\hline KX580606 & $93 \%$ & $\begin{array}{l}\text { Third stage larvae (long form) of Contracaecum sp. } \\
\text { found in L. niloticus (Lake Nasser, Egypt) }\end{array}$ & Younis et al 2017 \\
\hline KX580603 & $88 \%$ & $\begin{array}{l}\text { Third stage larvae of Contracaecum sp. found in } \\
\text { Oreochromis niloticus (Lake Nasser, Egypt) }\end{array}$ & Younis et al 2017 \\
\hline KF990491 & $88 \%$ & $\begin{array}{l}\text { Third stage larvae of Contracaecum sp. found in } H \text {. } \\
\text { forskahlii (Lake Turkana, Kenya) }\end{array}$ & Otachi et al 2015 \\
\hline KX580602 & $86 \%$ & $\begin{array}{l}\text { Third stage larvae of Contracaecum sp. found in } \\
\text { Tilapia galilae (Lake Nasser, Egypt) }\end{array}$ & Younis et al 2017 \\
\hline $\begin{array}{l}\text { AM940056 } \\
\text { AM940059 }\end{array}$ & $85 \%$ & $\begin{array}{l}\text { Adults of C. multipapillatum (D) found in Austral- } \\
\text { ian pelican (Pelecanus conspicillatus) }\end{array}$ & Shamsi et al 2008 \\
\hline $\begin{array}{l}\text { AM940062 } \\
\text { AM940063 } \\
\text { AM940064 }\end{array}$ & $84 \%$ & $\begin{array}{l}\text { Adults of C. pyripapillatum found in Australian peli- } \\
\text { can (Pelecanus conspicillatus) }\end{array}$ & Shamsi et al 2008 \\
\hline KX580605 & $79 \%$ & $\begin{array}{l}\text { Third stage larvae (long form) of Contracaecum sp. } \\
\text { found in H. forskahlii (Lake Nasser, Egypt) }\end{array}$ & Younis et al 2017 \\
\hline
\end{tabular}




Table 2: ITS-2 Sequences retrieved from GenBank database and producing significant alignments to
the newly deposited ITS-2 sequence of Contracaecum quadripapillatum n. sp. (KY703768).
\begin{tabular}{|c|c|l|l|}
\hline Accession & Identity & \multicolumn{1}{|c|}{ Source (L3/adult worms) } & \multicolumn{1}{|c|}{ References } \\
\hline KX580612 & $99 \%$ & $\begin{array}{l}\text { Third stage larvae (short form) of Contracaecum } \\
\text { sp. found in Lates niloticus (Lake Nasser, Egypt) }\end{array}$ & Younis et al. 2017 \\
\hline KX580610 & $99 \%$ & $\begin{array}{l}\text { Third stage larvae (short form) of Contracaecum } \\
\text { sp. found in Hydrocynus forskahlii (Lake Nasser, } \\
\text { Egypt) }\end{array}$ & Younis et al. 2017 \\
\hline $\begin{array}{l}\text { FM210437 } \\
\text { FM210438 } \\
\text { FM210439 }\end{array}$ & $98 \%$ & $\begin{array}{l}\text { Third stage larvae of Contracaecum sp. found in } \\
\text { barboid fishes (Parishan Lake, Iran) }\end{array}$ & $\begin{array}{l}\text { Unpublished: recorded by } \\
\text { Shamsi to GenBank } 2008\end{array}$ \\
\hline KM273050 & $95 \%$ & $\begin{array}{l}\text { Third stage larvae of C. osculatum found in liver of } \\
\text { Baltic cod Gadus morhua } \text { (Island of Bornholm, the } \\
\text { southern Baltic Sea) }\end{array}$ & Mehrdana et al. 2014 \\
\hline KX 580608 & $88 \%$ & $\begin{array}{l}\text { Third stage larvae of Contracaecum sp. found in } \\
\text { Tilapia galilae (Lake Nasser, Egypt) }\end{array}$ & Younis et al. 2017 \\
\hline KX 580609 & $88 \%$ & $\begin{array}{l}\text { Third stage larvae of Contracaecum sp. found in } \\
\text { Oreochromis niloticus (Lake Nasser, Egypt) }\end{array}$ & Younis et al. 2017 \\
\hline MG515224 & $84 \%$ & $\begin{array}{l}\text { Third stage larvae of Contracaecum overstreeti } \\
\text { found in marine fishes collected in Turkish waters }\end{array}$ & $\begin{array}{l}\text { Unpublished: recorded by } \\
\text { GenBank } 2017\end{array}$ \\
\hline
\end{tabular}

\section{Discussion}

In the present study, a new species of Contracaecum is identified by integrated morphological and molecular evidences named C. quadripapillatum n. sp. Third stage larvae were collected from $C$. lazera and adults were obtained experimentally from white pelicans.

All examined $C$. lazera were found infected with $3^{\text {rd }}$ stage larvae of Contracaecum sp. in the body cavity adhering to the alimentary canal. Numerous studies have been made concerning the presence of Contracaecum spp. (Anisakidae) in marine, brackish and freshwater fishes (Paperna, 1974). Donnelly and Hustler (1986) and Barson (2004) explained the low prevalence of Contracaecum sp. in Clarias gariepinus collected from Lake Chivero, Zimbabwe for the abundance of reed cormorants and darters which mainly prey on cichlids and rarely on Clarias. On the other hand, Barson and Avenant-Olde wage (2006) estimated a high prevalence $(86 \%)$ and mean intensity (16.3) of third stage larvae of Contracaecum spp. in abdominal cavity of Clarias gariepinus from the Rietvlei Dam near Pretoria, South Africa. Moyo (2009) found that C. gariepinus in Insukamini Dam, Zimbabwe was not infected.

During this study, experimental infection was successful in white pelicans which were infected with the third stage larvae, isolated from Clarias lazera. Eggs were detected in the feces on day 10 post-infection. $4^{\text {th }}$ stage larvae and adults were found in the lower part of the esophagus of the pelican. Morphological examinations revealed that little changes have been noticed in the structure during the development from third to fourth stage larvae. These changes were: the total body size, tail length, shape and size of lips and boring tooth, shape and size of anal opening.

Adult nematode identification was based on morphological features, such as the size and the shape of spicules (sexual organs) in males, anterior and posterior parts. Morphologically C. multipapillatum, is the most related species complex to the newly identified nematode in the present study. However, it showed clear and distinct differences from the 4 species which previously described as $C$. multipapillatum A, B, C and D (Nadler et al, 2000; Mattiucci et al, 2010; D'Amelio et al, 2007; Shamsi et al, 2008).

The molecular patterns of adult showed $100 \%$ identity to the larvae collected from C. lazera. Beside the identical morphological features, both ITS-1\& ITS-2 sequences showed very high similarities (98\%$100 \%)$ to sequences of the recently investigated larvae which infected $H$. forskahlii and L. niloticus from Lake Nasser (Younis et al, 2017). These data integrated with the phylogenetic sequence analyses and strongly indicating that larvae collected from $C$. lazera (present study) and from $H$. forskahlii and L. niloticus from (Younis et al, 2017) were of the same species ( $C$. quadripapillatum n. sp.). 
Interestingly, the very high sequence similarities (98\%) of both ITS-1 and ITS-2 between Contracaecum L3 isolated from $C$. lazera (present study) and Contracaecum L3 collected from Iranian fish by Shamsi and Aghazadeh-Meshgi (2011), might indicate that they likely belong to the same species (C. quadripapillatum n. sp.). But, this may need to be confirmed by further experiment and completing the life cycle of L3 collected by Shamsi and Aghazadeh-Meshgi (2011) to examine the adult stages. The alignments of ITS- 1 and ITS- 2 of the present materials (L3 and male) differs greatly (>12\%) from the previously identified genotypes of $C$. multipapillatum $\mathrm{A}, \mathrm{B}, \mathrm{C} \& \mathrm{D}$, which were reported from Europe, USA and Australia.

Based on the integrated morphological and molecular data presented in the current work, it was able to answer the question remained in the recent study by Younis et al. (2017): yes, there is more than one species of Contracaecum infected the lake Nasser fish and there is a new species (fifth species) of the $C$. multipapillatum complex. L3 collected from $C$. lazera and its adult stages obtained experimentally from white pelican as well as short forms of L3 collected previously from $H$. forskahlii and L. niloticus are belonging to a new species named $C$. quadripapillatum n. sp. Work is continuing to identify all the Contarcaecum sp. by completion of the life cycle of the larvae that infect other species of Lake Nasser fish.

\section{Conclusion}

Detailed morphological description of both larvae (L3) and adults, by light and scanning electron microscopes as well as molecular analysis of the related sequences of the internal transcribed spacers of nuclear ribosomal DNA (ITS-1 and ITS-2) indicated the presence of a new Contracaecum sp. named here C. quadripapillatum n. sp.

\section{Acknowledgments}

The authors would like to thank the Assistant Team at the Zoology Department, Faculty of Science, Aswan University and at the Fishery Management Center, High Dam La- ke Development Authority for providing the technical assistance during this work.

\section{References}

Amare, A, Alemayehu, A, Aylate, A, 2014: Prevalence of internal parasitic helminthes infected Oreochromis niloticus (Nile Tilapia), $\mathrm{Cl}$ arias gariepinus (African Catfish) and Cyprinus carpio (Common Carp) in Lake Lugo (Hayke), Northeast Ethiopia. J. Aquacult. Res. Develop. 5:233. http://dx.doi. org/10.4172/2155-9546. 1000233.

Anderson, RC, 1992: Nematode Parasites of Vertebrates: Their Development and Transmission. CABI Publishing; CAB International; Wallingford, Oxon, U.K.

Anderson, RC, 2000: Nematode Parasites of Vertebrates: Their Development and Transmission, $2^{\text {nd }}$ Edition, Walingford, UK, CABI Publishing.

Audicana, MT, Ansotegui, IJ, De Corres, LF, Kennedy, MW, 2002: Anisakis simplex: Dangerous-dead and alive? Trends Parasitol. 18:20-5.

Barson, M, 2004: The occurrence of Contracaecum sp. larvae (Nematoda: Anisakidae) in the catfish Clarias gariepinus (Burchell) from Lake Chivero, Zimbabwe. Onderstepoort J. Vet. Res. 71, 1:35-9.

Barson, M, Avenant-Oldewage, A, 2006: Nematode parasites of Clarias gariepinus (Burchell, 1822) from the Rietvlei Dam, South Africa Onderstepoort J. Vet. Res. 73:87-94.

D'Amlio, S, Barros, NB, Ingrosso, S, Fauquier, DA, Russo, R, et al, 2007: Genetic characterization of members of the genus Contracaecum (Nematoda: Anisakidae) from fish-eating birds from west-central Florida, USA, with evidence of new species. Parasitol. 134: 1041-51.

Deardorff, TL, Overstreet, RM, 1980: Contracaecum multipapillatum (=C. robustum) from fishes and birds in the northern Gulf of Mexico. J. Parasitol. 66: 853-6.

Dereeper, A, Guignon, V, Blanc, G, Audic, S, Buffet, S, et al, 2008: Phylogeny.fr: robust phylogenetic analysis for the non-specialist. Nucl. Acids Res. 36:465-9.

Donnelly, BG, Hustler, K, 1986: Notes on the diet of the reed cormorant and darter on Lake Kariba during 1970 \& 1971. Arnoldia Zimbabwe 9:319-32.

Dronen, N, Blend, C, Anderson, C, 2003: Endohelminths from the Brown Pelican, Pelecannus occidentalis, and the American White Peli- 
can, Pelecanus erythrorhynchus, from Galveston Bay, Texas, U.S.A., and Checklist of Pelican Parasites. Comparat. Parasitol. 70, 2:140-54.

Farjallah, S, Merella, P, Ingrosso, S, Rotta, A, Slimane, BB, et al, 2008: Molecular evidence for the occurrence of Contracaecum rudolphii A (Nematoda: Anisakidae) in shag Phalacrocorax aristotelis (Linnaeus) (Aves: Phalacrocoracidae) from Sardinia (western Mediterranean Sea). Inter. J. Parasitol. 57:437-40.

Kaneko, JJ, 1991: Parasite hazards of public health significance to U.S. consumers of raw fish. IAAA Proc. 22:130-4.

Klimpel, S, Kellermanns, E, Palm, HW, Moravec, F, 2007: Zoogeography of fish parasites of the pearlside (Maurolicus muelleri), with genetic evidence of the Anisakis simplex (s.s.) from the Mid-Atlantic Ridge. Mari. Biol 152, 3:725-32.

Koie, M, Fagerholm, H, 1995: The life cycle of Contracaecum osculatum (Rudolphi, 1802) sensu stricto (Nematoda, Ascaridoida, Anisakidae) in view of experimental infections. Parasitol. Res. 81:481-9.

Koie, M, Berland, B, Burt, MD, 1995: Development to third stage larvae occurs in the eggs of Anisakis simplex and Pseudoterranova decipiens (Nematoda, Ascaridoidea, Anisakidae). Canad. J. Fisher. Aquat. Sci. 52, 1:134-9.

Latif, AFA, 1974: Fisheries of Lake Nasser. Aswan Regional Planning, Lake Nasser Development Center, Egypt, ARE.

Lile, NK, 1998: Alimentary tract helminths of four pleuronectid flatfish in relation to host phylogeny and ecology. J. Fish Biol. 53:945-53.

Martins, ML, Onaka, EM, Fenerick, JJr, 2005: Larval Contracaecum sp. (Nematoda: Anisakidae) in Hoplias malabaricus and Hoplerythrinus unitaeniatus (Osteichthyes: Erythrinida e) of economic importance in occidental marshlands of Maranha o, Brazil. Vet. Parasitol. 127: 51-9.

Mattiucci, S, Nascetti, G, 2008: Advances and trends in the molecular systematics of anisakid nematodes, with implications for their evolutionary ecology and host-parasite co-evolutionary processes. Adv. Parasitol. 66:147-8.

Mattiucci, S, Paoletti, M, Solorzano, AC, Nascetti, G, 2010: Contraceacum gibsoni n. sp. and C. overstreeti n. sp. (Nematoda: Anisakidae) from the Dalmatian pelican Pelecanus crispus (L.) in Greek waters: genetic and morghological evidence. Syst. Parasitol. 75:207-24.

Mehrdana, F, Bahlool, QZ, Skov, J, Marana,
MH, Sindberg, D, et al, 2014: Occurrence of zoonotic nematodes Pseudoterranova decipiens, Contracaecum osculatum and Anisakis simplex in cod (Gadus morhua) from the Baltic Sea. Vet. Parasitol. 205, 3/4:581-7.

Moyo, DZ, 2009: Observations on the Helminth Parasites of Fish in Insukamini Dam, Zembabwe. Res. J. Agric. Biol. Sci. 5, 5:782-5.

Moyo, G, Barson, M, 2010: Diversity of metazoan parasites of the African catfish Clarias gariepinus (Burchell, 1822) as indicators of pollution in a subtropical African river system. J. Helminthol. 84: 216-27.

Nadler, SA, Hudspeth, DS, 1998: Ribosomal DNA and phylogeny of the Ascaridoidea (Nemata: Secernentea): implications for morphological evolution and classification. Mol. Phylogen. Evol. 10:221-36.

Nadler, SA, D'Amelio, S, Fagerholm, HP, Berland, B, Paggi, L, 2000: Phylogenetic relation-ships among species of Contracaecum and Phocascaris (Nematoda, Ascaridoida) based on nuclear rDNA. Parasitology 121:455-63.

Nadler, SA, D'Amelio, S, Dailey, MD, Paggi, L, Siu, S, et al, 2005: Molecular phylogenetics and diagnosis of Anisakis, Pseudoter-ranova, and Contracaecum from Northern Pacific marine mammals. J. Parasitol. 91, 6:1413-29.

Olivero-Verbel, J, Baldiris-Avila, R, GuetteFernandez, J, Benavides-Alvarez, A, Mercado-Camargo, J, et al, 2006: Contracaecum sp. infection in Hoplias malabaricus (moncholo) from rivers and marshes of Colombia. Vet. Parasitol. 140, 1/2: 90-97.

Otachi, EO, Szostakowska, B, Jirsa, F, Fellner-Frank, C, 2015: Parasite communities of the elongate tigerfish Hydrocynus forskahlii (Cuvier 1819) and red belly tilapia Tilapia zillii (Gervais 1848) from Lake Turkana, Kenya: influence of host sex and size. Acta Parasitol. 60:9-20.

Palm, HW, 2004: The Trypanorhyncha diesing. 1863. PKSPL-IPB Press, Bogor

Paperna, I, 1974: Larval Contracaecum in the pericardium of fishes from East African Lakes. Proc. Helminthol. Soc. Washington 41:252-8.

Raillient, A, Henry, A, 1912: Observation surles Strongylides du genre Nematodirus (Observation of Strongylides of the genus Nematodir$u s)$. Bull. Soc. Pathol. Exot. 5:35-9 (In French).

Sakanari, JA, Mckerrow, JH, 1989: Anisakiasis. Clin. Microbiol. Rev. 2:278-84.

Shamsi, S, Aghazadeh-Meshgi, M, 2011: Mor- 
phological and genetic characterization of selected Contracaecum (Nematoda: Anisakidae) larvae in Iran. Iran. J. Fisher. Sci. 10, 2:356-61.

Shamsi, S, Gasser, R, Beveridge, I, Shabani, AA, 2008: Contracaecum pyripapillatum n. sp. (Nematoda: Anisakidae) and a description of $C$. multipapillatum (von Drasche, 1882) from the Australian pelican, Pelecanus conspicillatus. Parasitol. Res. 103:1031-9.

Shamsi, S, Norman, R, Gasser, R, Beveridge, I, 2009: Redescription and genetic characterization of selected Contracaecum spp. (Nematoda: Anisakidae) from various hosts in Australia. Parasitol. Res. 104:1507-25.

Shih, HH, 2004: Parasitic helminth fauna of the cutlass fish, Trichiurus lepturus L., and the differentiation of four anisakid nematode third-stage larvae by nuclear ribosomal DNA sequences. Parasitol. Res. 93, 3:188-95.

Torres, P, Sierpe, V, Schlatter, R, 1983: Occurrence of Contracaecum rudolphii in new hosts in Chile. Z. Parasitenkd. 69:397-9.

Whitfield, AK, Heeg, J, 1977: On the life cycles of the cestode Ptychobothrium belones and nematodes of the genus Contracaecum from Lake St. Lucia, Zululand. South Afri. J. Sci. 73: 121-2.

William, GD, Ernest, HW, Antonio, A, Nilda, MJ, Lucy, B, et al, 2002: Helminth and arthropod parasites of the brown pelican, Pelecanus occidentalis, in Puerto Rico, with a compilation of all metazoan parasites reported from this host in the Western Hemisphere. Avi. Pathol. 31, 5: 441-8.

Yamaguti, S, 1961: Systema Helminthum, Vol. 3. The Nematodes of Vertebrates, Part I \& II. In- terscience Publishers, Inc., New York, London. Yimer, E, Enyew, M, 2003: Parasites of Fish at Lake Tana, Ethiopia. Ethiopian J. Sci. 26, 1:1-6. Younis, AE, Frank Geisinger, F, Ajonina-Ekoti, I, Soblik, H, Steen, H, et al, 2011: Stagespecific excretory-secretory small heat shock proteins from the parasitic nematode Strongyloides ratti-putative links to host's intestinal mucosal defense system. FEBS J. 278:3319-36.

Younis, AE, Saad, AI, Rabei, JM, 2017: The occurrence of Contracaecum sp. larvae (Nematoda: Anisakidae) in four teleostean species from Lake Nasser, Egypt: Morphological and molecular studies. J. Basic Appl. Zool. 78: 9. http:// dx. doi. org/ 10.1186/s41936-017-0012-4.

Zhang, L, Hu, M, Shamsi, S, Beveridge, I, Li, $\mathbf{H}, \mathbf{X u}, \mathbf{Z}$, et al, 2007: The specific identification of anisakid larvae from fishes from the Yellow Sea, China, using mutation scanning-coupled sequence analysis of nuclear ribosomal DNA. Mol. Cell. Probes 21:386-90.

Zhu, XQ, Gasser, RB, Podolska, M, Chilton, NB, 1998: Characterization of anisakid nematodes with zoonotic potential by nuclear ribosomal DNA sequences. Inter. J. Parasitol. 28, 12:191121.

Zhu, XQ, Gasser, RB, Jacobs, DE, Hung, GC, Chilton, NB, 2000a: Relationships among some ascaridoid nematodes based on ribosomal DNA sequence data. Parasitol. Res. 86, 9:738-44.

Zhu, XQ, Gasser, RB, Chilton, NB, Jacobs, DE, 2001b: Molecular approaches for studying ascaridoid nematodes with zoonotic potential, with an emphasis on Toxocara species. J. Helminthol. 75, 2:101-8.

\section{Explanation of figures}

Fig. 1: Third stage larva of Contracaecum quadripapillatum n. sp. obtained from natural infection of Clarias lazera. Scanning electron micrographs (a) anterior part showing lips; (b) posterior part showing anal opening and tail

Fig. 2: Fourth stage larva of Contracaecum quadripapillatum n. sp. obtained from experimental infection of white pelican. Scanning electron micrographs (a) anterior part showing the three lips one dorsal DL and two ventral VL, mouth opening, and excretory pore; (b) posterior part showing the beginning of the molting, anus, tapered process and tail; (c) molting process

Fig. 3: Adult of Contracaecum quadripapillatum n. sp. obtained from experimental infection of white pelican (a) anterior part of nematode showing dorsal labium, interlabia and esophagus; (b) ventriculus and ventricular appendix; (c) posterior part of male showing the two spicules and seminal vesicle; (d) posterior end in male, ventral view, showing arrangement of post-cloacal papillae

Fig. 4: Adult of Contracaecum quadripapillatum n. sp. obtained from experimental infection of white pelican (a) Light microscope photo of anterior part of male showing lips, interlabia and esophagus; (b) Light microscope photo showing ventriculus and ventricular appendix; (c) Light microscope photo of posterior part of male showing the two spicules; (d) Scanning electron micrograph of anterior part showing lips, interlabia, and papillae; (e) Scanning electron micrograph of posterior part showing spicule and arrangement of post-cloacal papillae; (f) Scanning electron micrograph of muscular genital pore of female surrounded by papillae

Fig. 5: Phylogenetic tree of the aligned 16 ITS-1 sequences from Contracaecum spp. including the ITS-1 sequences of $C$. quadripapillatum n. sp. (arrow), identified in this study, using the Phylogeny.fr program (http://www.phylogeny.fr/). Sequences from L3, 


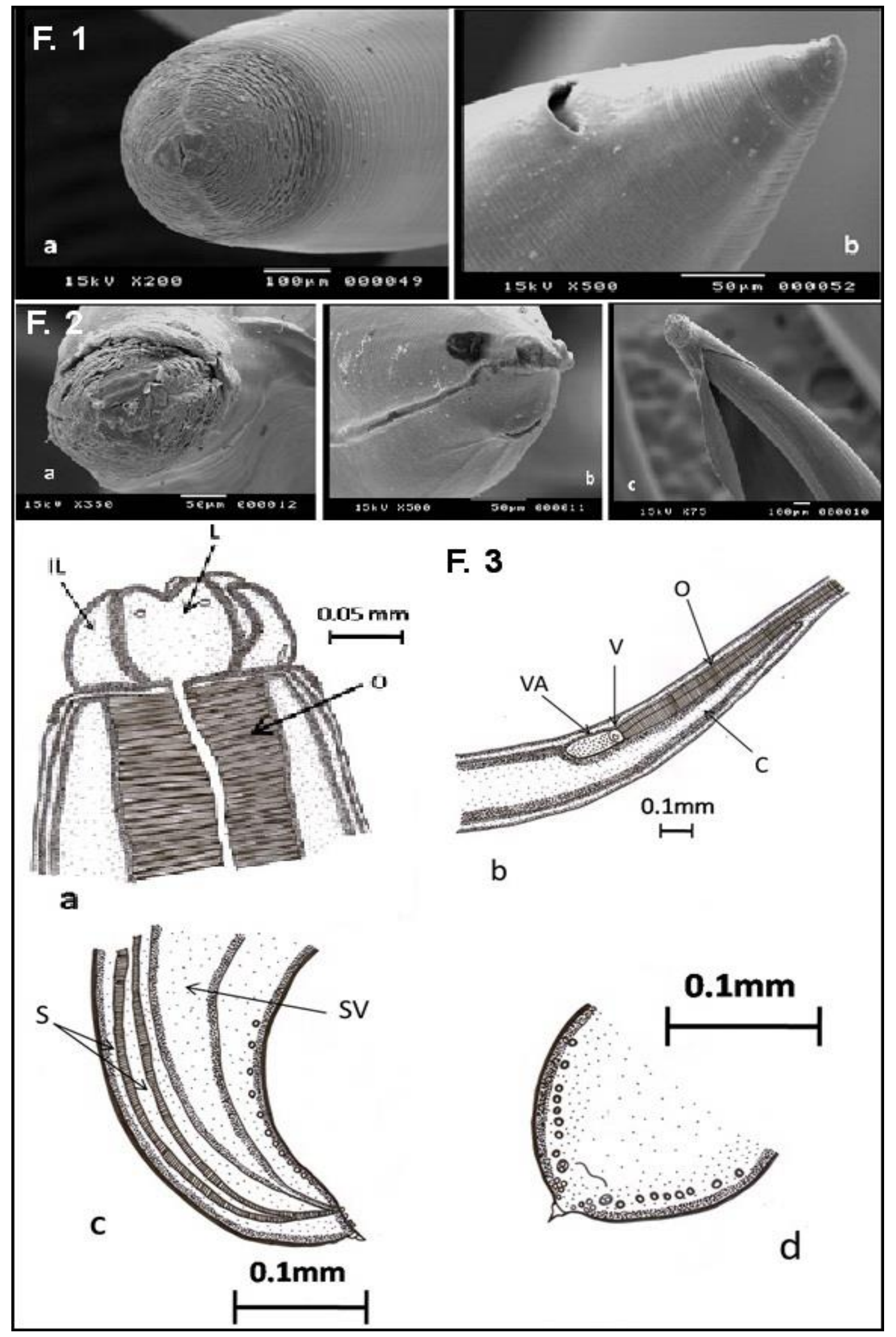



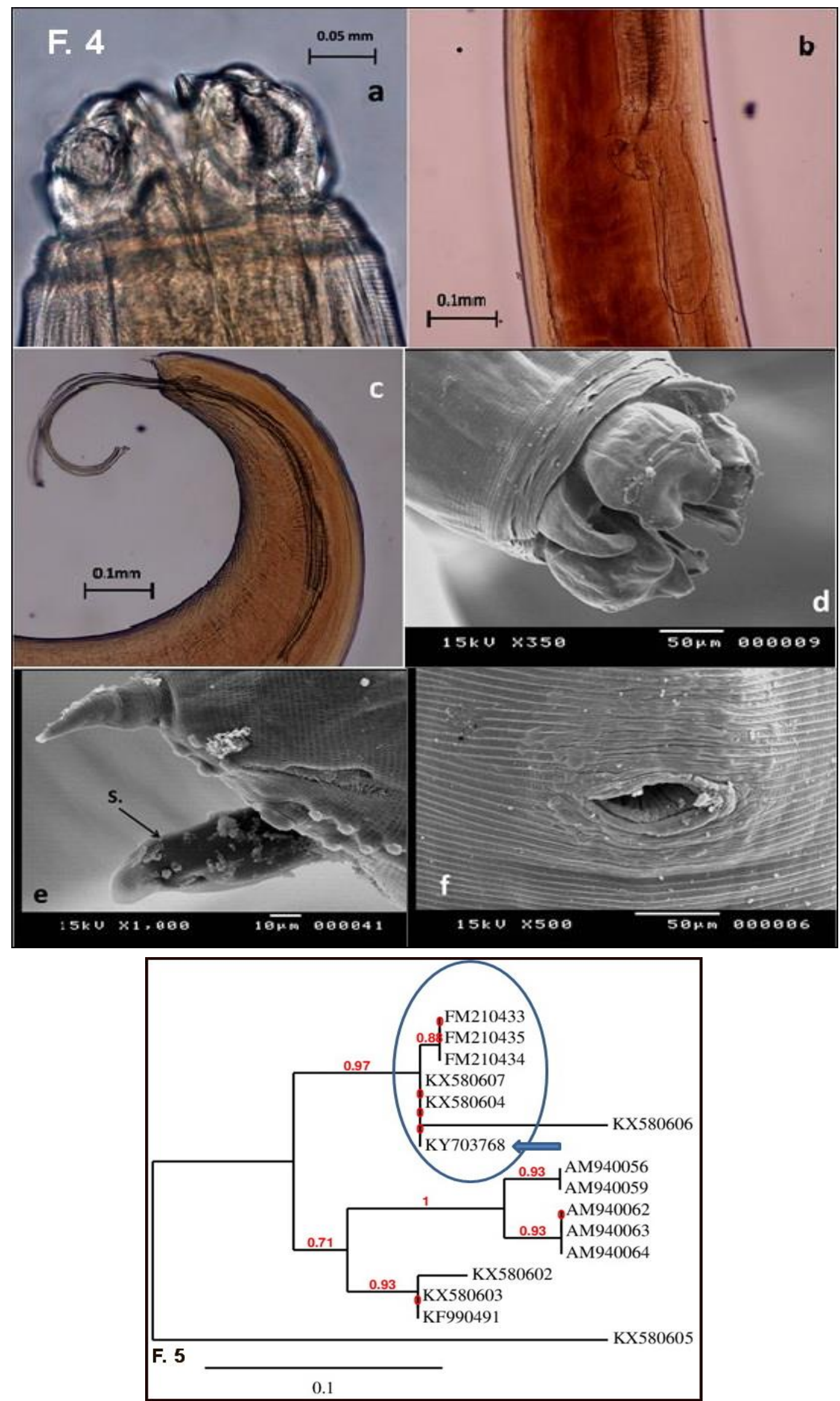